ACTA SOCIETATIS

BOTANICORUM POLONIAE

Vol. XLVII, nr $1-2$

1978

\title{
Influence of $1-\beta-D$-arabinofuranosylcytosine on mitotic activity of apical meristem of onion (Allium cepa L.) roots*
}

\author{
M. KURAS and A. MALINOWSKA \\ Laboratory of Electron Microscopy, Institute of Botany \\ Warsaw University \\ (Received: October 11, 1977.)
}

\begin{abstract}
The influence of increasing cytosine arabinoside (ara-C) concentration (50, 100,300 and $500 \mu \mathrm{g} / \mathrm{ml}$ ) on the mitotic activity of the apical meristem of onion adventitious roots was investigated during 24-h incubation in ara-C and postincubation in water.

Incubation in ara-C inhibits reversibly mitosis, the degree of inhibition being dependent on the concentration used. $50 \mu \mathrm{g} / \mathrm{ml}$ ara-C causes only a slight and transitional mitotic depression, while $100-500 \mu \mathrm{g} / \mathrm{ml}$ reduces the per cent of mitoses in various degrees after 12-h incubation whereas after $24 \mathrm{~h}$ all concentrations $(100-500)$ reduce mitosis to the same level of about 2 per cent $(80 \%$ inhibition). During postincubation in water there occurs after treatment with $100-500 \mu \mathrm{g} / \mathrm{ml}$ ara-C, a wave of highly synchronized mitoses with a peak after $12 \mathrm{~h}$. The highest frequency of synchronized mitoses $(60 \%)$ appeared in roots treated with $300 \mu \mathrm{g} / \mathrm{ml}$ ara-C. The main wave is preceded by a small one with a peak after $2-4 \mathrm{~h}$ of postincubation. This seems to be the consequence of phases $\mathrm{S}$ and $\mathrm{G}_{2}$ inhibition by ara-C.

It was found that under the influence of ara-C the per cent of mitoses with chromosome aberration and of cells with micronuclei increased only slightly.
\end{abstract}

\section{INTRODUCTION}

$1-\beta-D$-arabinofuranosylcytosine (arabinoside cytosine, ara-C) is a synthetic nucleoside with a structure resembling that of natural nucleoside cytidine and deoxycytidine.

Ara-C is known as an antimitotic used in the control of cancer. Intravenously applied it very effectively inhibits the development of

* This work was performed under a grant of the Polish Academy of Sciences (problem 09.7.3). 
many tumour transplants in mice, but does not affect rat tumours (Evans et al., 1964). Chu and Fischer (1962) found that ara-C inhibits the development of leukaemia without reducing ${ }^{3} \mathrm{H}$-uridine incorporation into RNA, but it inhibits DNA synthesis restored by deoxycytidine. This was confirmed by Borun et al., (1967) who claimed that ara-C of $40 \mu \mathrm{g} / \mathrm{ml}$ concentration completely inhibits DNA synthesis. These authors established at the same time that, beside inhibiting DNA synthesis, ara-C completely arrests within $30 \mathrm{~min}$. the synthesis of histones and of histone mRNA. Ara-C acts quicker than does actinomycin. The synthesis of DNA, and histones and the amount of labelled 7-9 S RNA in the polysomes diminished to zero during exposure to the action of ara-C. This inhibitor, however, does not affect other proteins and RNA. These results suggest that 7-9 S RNA is the histone mRNA.

Kihlman et al. (1963) demonstrated that $10^{-5} \mathrm{M}$ ara-C inhibits mitosis in human cells and causes chromosome aberrations.

The influence of ara-C on plant cells was not studied after the report of $\mathrm{Kihlman}(1966)$ that ara-C in concentration as high as $10^{-3} \mathrm{M}$ does not inhibit either mitosis or DNA synthesis in the roots of Vicia faba.

\section{MATERIAL and METHODS}

Selected equal-sized bulbs of onion (Allium cepa L., cf. W olska) were used. Roots were grown in darkness at constant temperature of $21^{\circ} \mathrm{C}\left( \pm 0.5^{\circ} \mathrm{C}\right)$ in tap water filtered through a charcoal filter, changed every $24 \mathrm{~h}$ and continuously aerated.

Incubation was run in a solution of ara-C (Calbiochem) in charcoal-filtered tap water of $50,100,300$ and $500 \mu \mathrm{g} / \mathrm{ml}$ concentration.

Roots of two bulbs were incubated in each concentration. The control consisted of roots of 2 bulbs growing in the course of the entire experiment in water. After $24 \mathrm{~h}$ of incubation, the roots of the experimental and control bulbs were washed repeatedly with tap water and transferred to a vessel with filtered tap water for $48 \mathrm{~h}$ of postincubation. The same conditions were maintained during incubation and postincubation as before: darkness, constant temperature, aeration of the solutions and water exchange at $24-\mathrm{h}$ intervals. Samples $(1-3$ roots from each bulb) were taken at the moment of starting the experiment (zero time), after 12 and $24 \mathrm{~h}$ of incubation and at 2 -h intervals from 0 to $32 \mathrm{~h}$ of postincubation and further after 36 and $48 \mathrm{~h}$ of postincubation.

The $0.5 \mathrm{~cm}$ long root apices were fixed for $2 \mathrm{~h}$ in acetoalcohol (1:3), washed with 96 per cent ethanol for $0.5 \mathrm{~h}$ and in 80 per cent ethanol in which the material was stored. The apices $3 \mathrm{~mm}$ long were stained 
and macerated in 2 per cent acetoorcein with $1 \mathrm{~N} \mathrm{HCl}(9: 1)$ for $2 \mathrm{~h}$ at room temperature and permanent squashes were prepared by the dry ice method.

Microscopic analysis of the smears comprised:

1. Calculation of the mitotic index (per 1000 meristematic cells) by the Lopez-Saez and Fernandez-Gomez method (1965),

2. Calculation of the phase indices (per 200 dividing cells),

3 . Calculation of the aberration index (per 200 mitoses) and micronuclei index (per 1000 meristematic cells).

All calculations were carried out in each combination for individual roots, and then the mean indices were computed for the roots of both bulbs.

\section{RESULTS}

\section{Changes in mitotic index}

Mitotic index in roots of control bulbs.

In the roots of both control bulbs $\left(\mathrm{K}_{\mathrm{I}}\right.$ and $\left.\mathrm{K}_{\mathrm{II}}\right)$ rather wide oscillations of the mitotic index were noted, both in single roots of the same bulb and in the mean index for the roots of each bulb, for the time of duration of the experiment. The mean mitotic index for the roots of $\mathrm{K}_{\mathrm{I}}$ was 9.01 per cent (varying between 6.1 and $13.6 \%$ ) and for $\mathrm{K}_{\mathrm{II}}$ it was 10.63 per cent (varying between 7.8 and $12.6^{\circ} \%$ ). The mean mitotic index calculated for the roots of both bulbs was 9.8 per cent (Fig. 1; Plate I, photo 1).

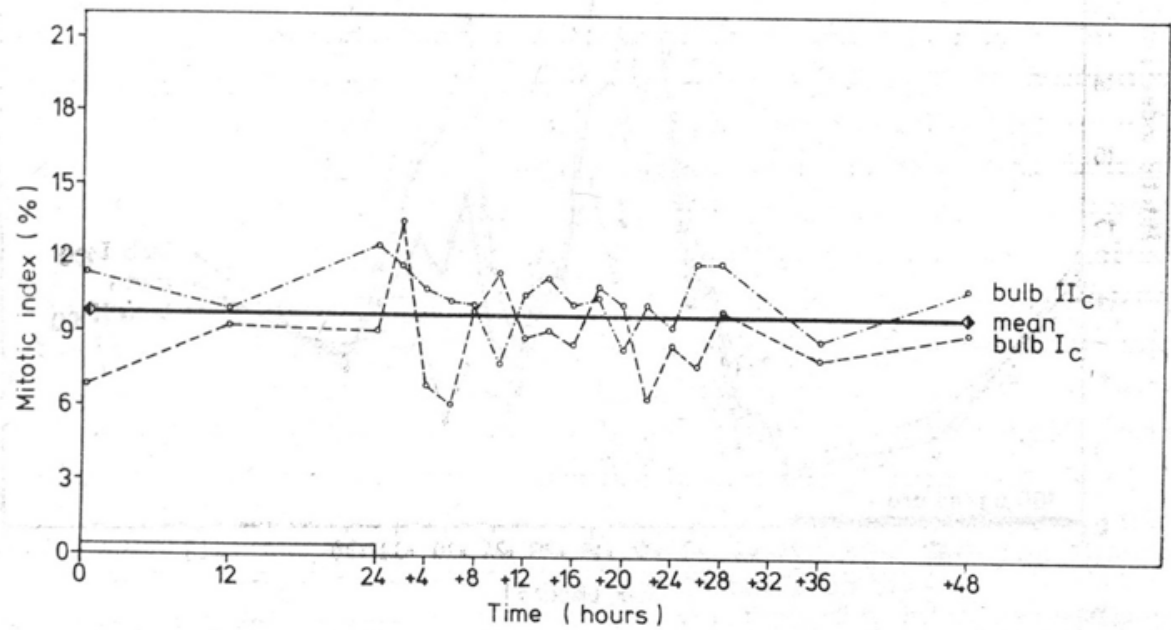

Fig. 1. Mitotic index in apical meristem of control onion roots 


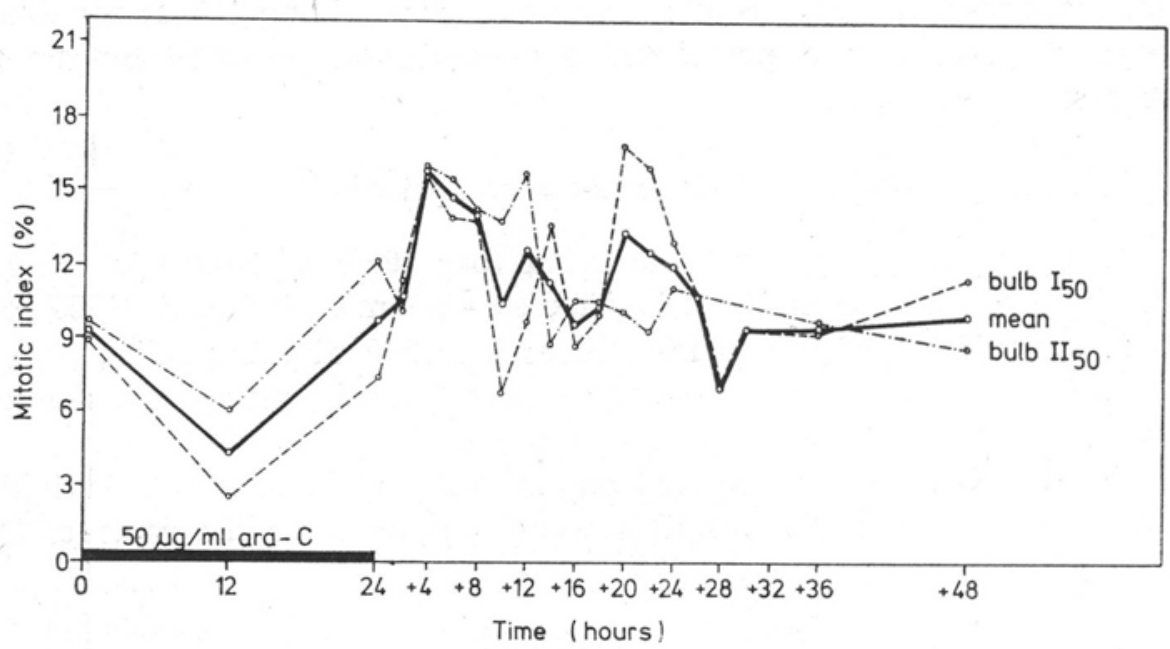

Fig. 2. Mitotic index in apical meristem of onion roots during 24-h incubation in $50 \mu \mathrm{g} / \mathrm{ml}$ ara-C and $48-\mathrm{h}$ postincubation in $\mathrm{H}_{2} \mathrm{O}$

The mitotic indices for the roots of experimental bulbs were similar at the beginning of the experiment to that for the controls (8.8 and $11.2 \%$, Figs $2-5$ ).

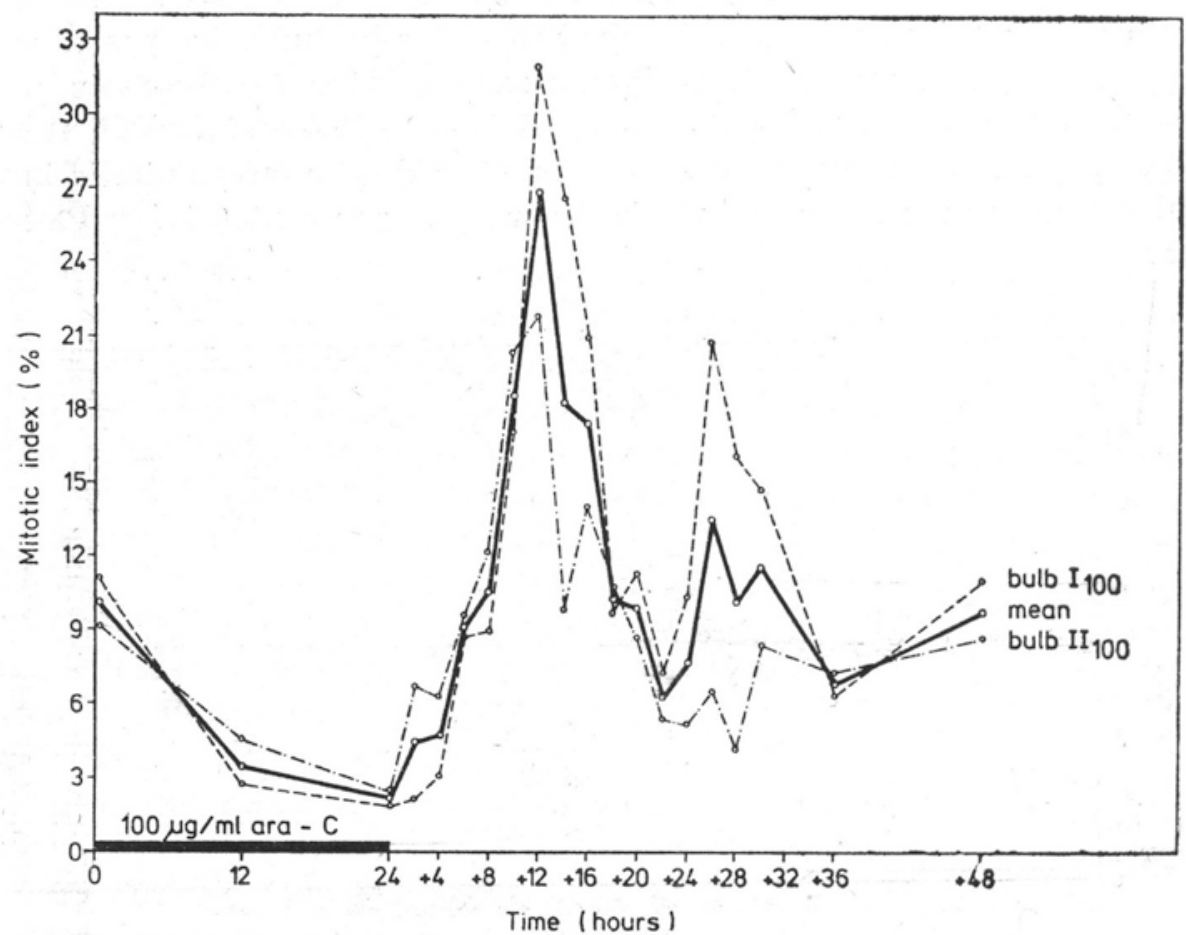

Fig. 3. Mitotic index in apical meristems of onion roots during 24-h incubation in $100 \mu \mathrm{g} / \mathrm{ml}$ ara-C and $48-\mathrm{h}$ postincubation in $\mathrm{H}_{2} \mathrm{O}$ 


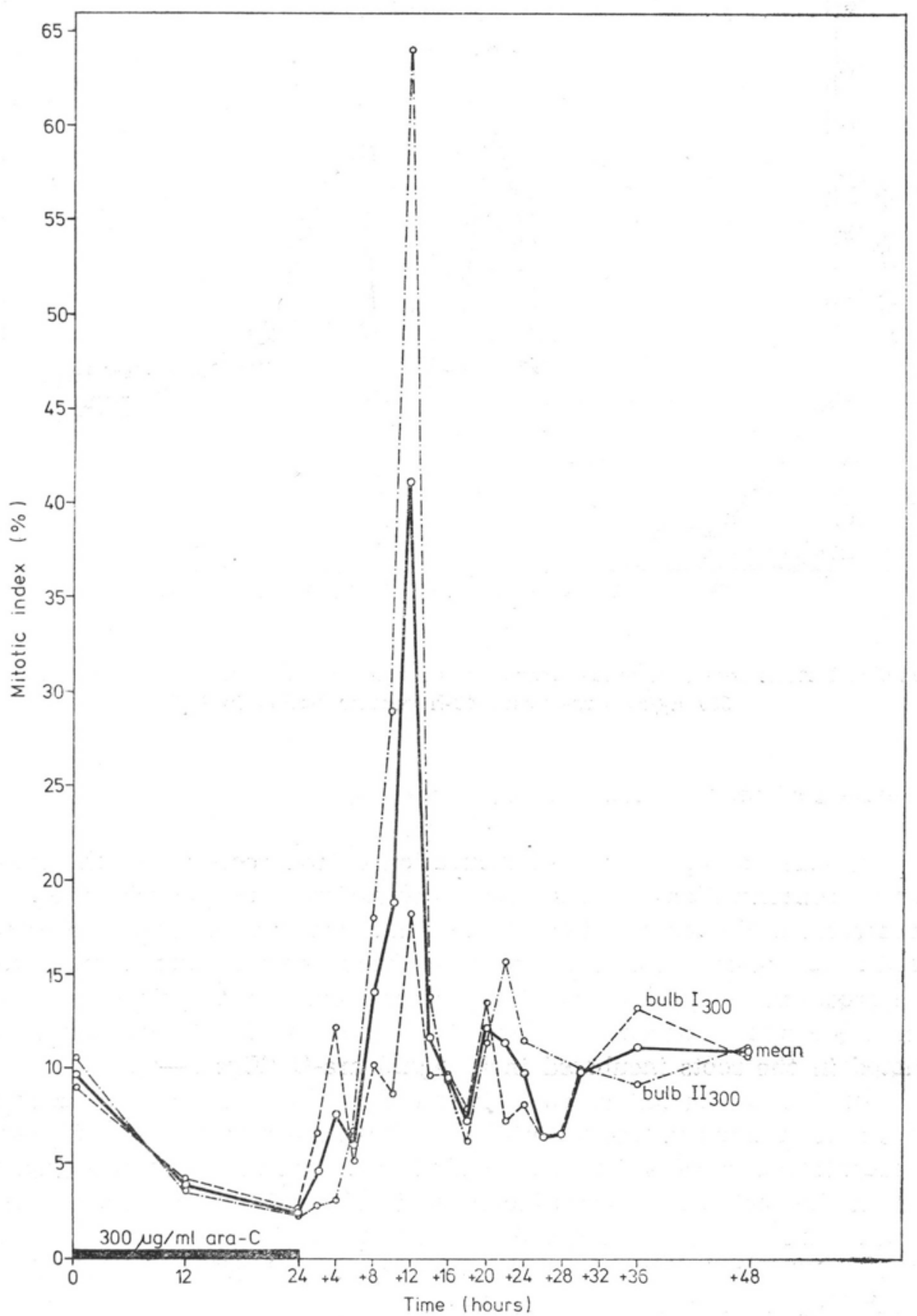

Fig. 4. Mitotic index in apical meristems of onion roots during 24-h incubation ir $300 \mu \mathrm{g} / \mathrm{ml}$ ara-C and $48-\mathrm{h}$ postincubation in $\mathrm{H}_{2} \mathrm{O}$ 


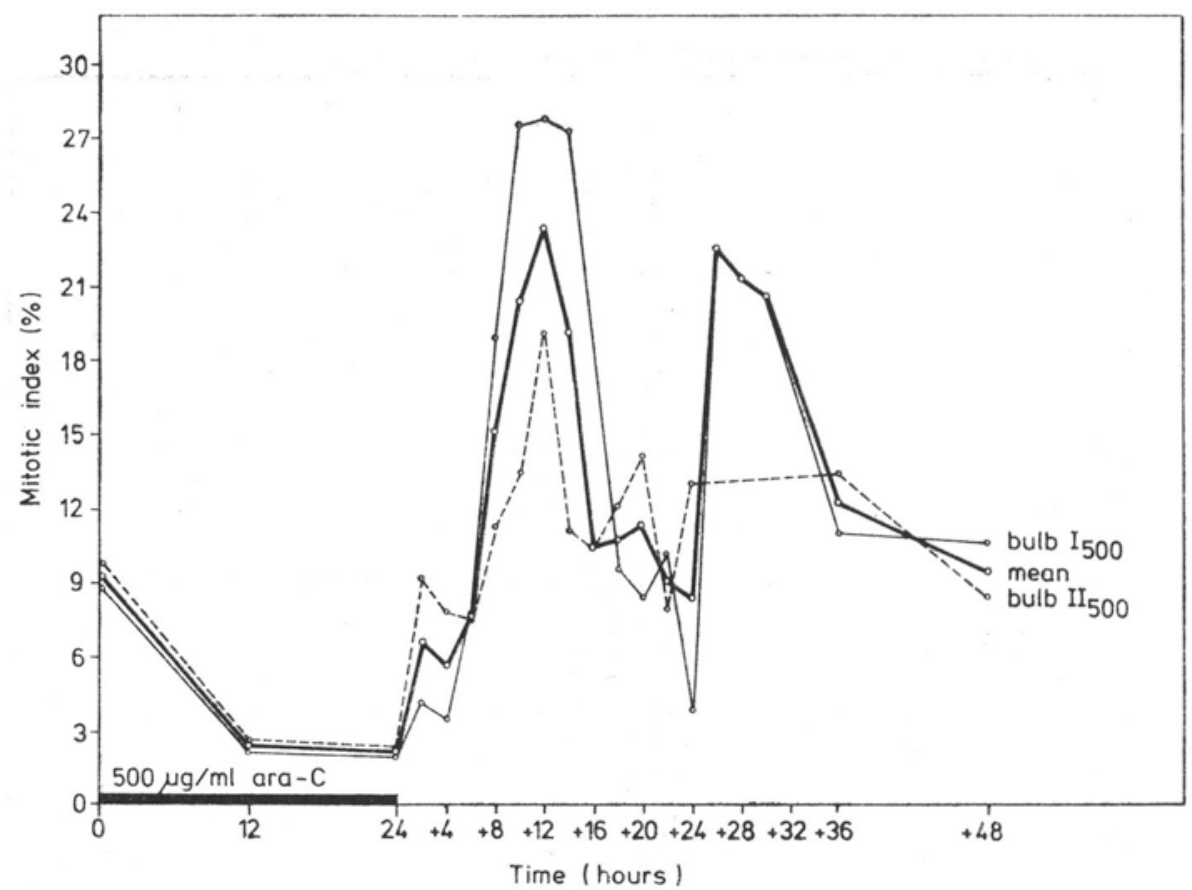

Fig. 5. Mitotic index in apical meristem of onion roots during 24-h incubation in $500 \mu \mathrm{g} / \mathrm{ml}$ ara-C and 48-h postincubation in $\mathrm{H}_{2} \mathrm{O}$

Changes of mitotic index during incubation

As early as after $12 \mathrm{~h}$ of incubation of the roots in all the tested ara-C concentrations, a considerable depression of the mitotic index was observed. Inhibition of mitosis at this time was proportional to the concentration of ara-C. The lowest mean value of the mitotic index (for the roots of both bulbs) was 2.3 per cent found in the roots incubated in a $500 \mu \mathrm{g} / \mathrm{ml}$ concentration and the highest value, 4.3 per cent, was noted in the roots incubated in $50 \mu \mathrm{g} / \mathrm{ml}$ ara-C (Figs $1-6$ ).

Further incubation of roots in ara-C $(12-24 \mathrm{~h})$ variously affected the mitotic activity. The mitotic index for roots incubated in a $50 \mu \mathrm{g} / \mathrm{ml}$ concentration increased to a level similar to that in the control (Fig. 2).

In the roots of all bulbs incubated in 100 and $300 \mu \mathrm{g} / \mathrm{ml}$ ara-C concentrations, a further depression of mitotic activity occurred (in bulb $\mathrm{I}_{100}$ to 1.9 and in bulb $\mathrm{II}_{100}$ to 2.6 per cent, in bulb $\mathrm{I}_{300}$ to 1.5 and in bulb $\mathrm{II}_{300}$ to 1.3 per cent, Figs $3-4$ ).

Prolongation of the incubation of roots in the highest ara-C concentration did not change the mitotic index (bulb $\mathrm{I}_{500}-2.2$ and 2.0 per cent after, 12 and $24 \mathrm{~h}$, respectively, and bulb $\mathrm{II}_{500} 2.5$ and 2.4 per cent after 12 and 24 h, respectively, Fig. 5). 


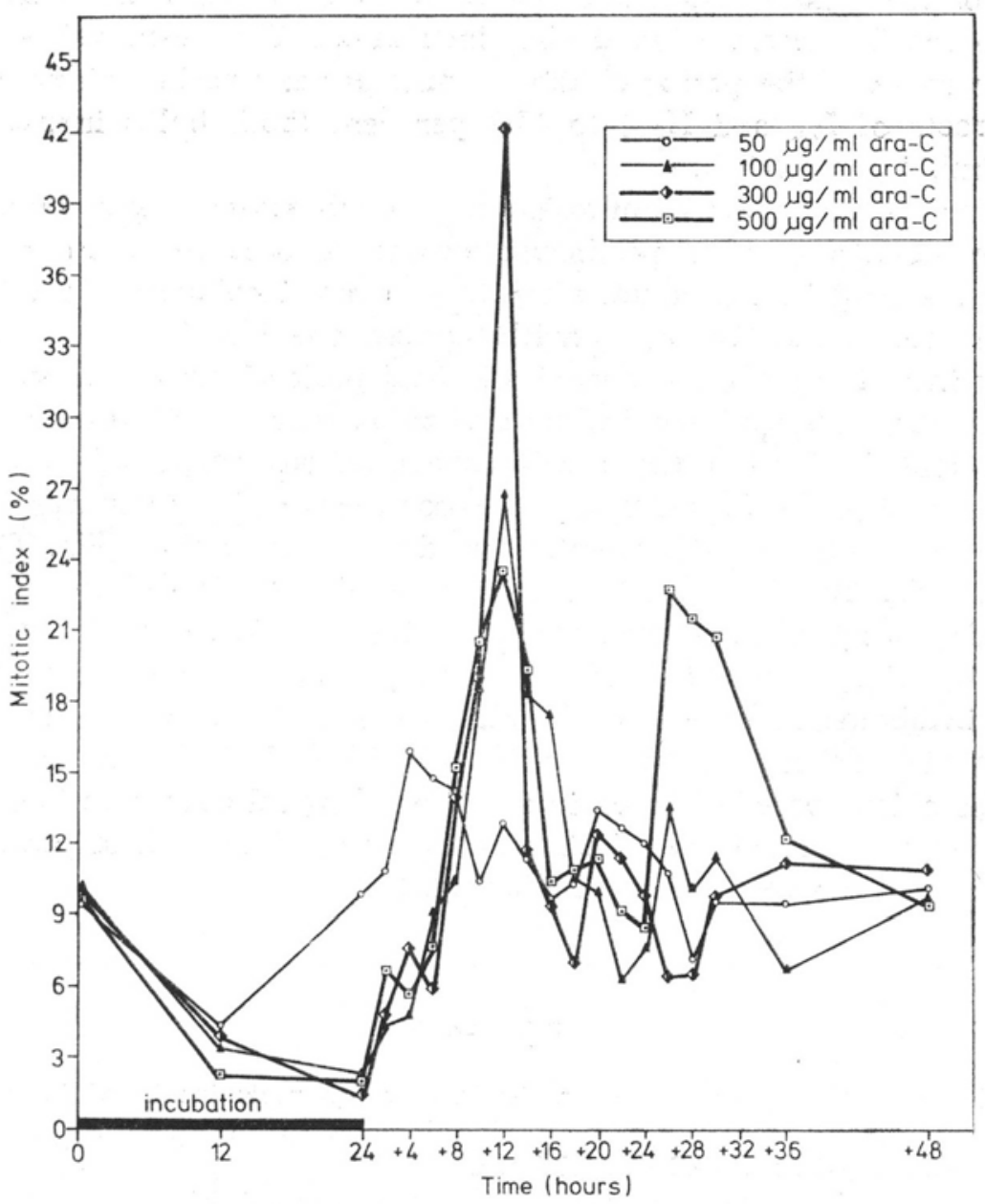

Fig. 6. Mitotic indices in apical meristem of onion roots incubated in 50, 100, 300 and $500 \mu \mathrm{g} / \mathrm{ml}$ ara-C

It results from these data that none of the ara-C concentrations tested caused within $24 \mathrm{~h}$ of incubation a complete disappearance of mitosis. In all the incubated roots treated with $100-500 \mu \mathrm{g} / \mathrm{ml}$ concentrations the mitotic index decreased always to about 2 per cent.

Inhibition of mitotic activity after $24 \mathrm{~h}$ of incubation in ara-C of $300 \mathrm{mg} / \mathrm{ml}$ concentration is shown in photo 2 (Plate I).

Changes in mitotic index during postincubation

Already in the first hours after abolition of the inhibitor action, a renewed wave of mitotic activity appeared leading after $2-4 \mathrm{~h}$ of postincubation to the first small peak of mitosis at which the mean 
value of the mitotic index is different for various bulbs and dependent on the ara-C concentration during incubation. The mean value of the mitotic index in the period of the 1 st mitosis peak varied within 4.2 per cent (roots of $\mathrm{I}_{500}$ and $\mathrm{II}_{500}$ ) to 15.9 per cent (both bulbs incubated in $50 \mu \mathrm{g} / \mathrm{ml}$, figs 2 and 6 ).

After the first peak of mitosis and the subsequent slight decrease of mitotic activity ( $6 \mathrm{~h}$ of postincubation) there occurred a renewed increase reaching its maximum after $12 \mathrm{~h}$ of postincubation. At this time in the roots of all bulbs, notwithstanding the inhibitor concentration during incubation, there occurred a second peak of mitosis at which the mean value of the mitotic index reached as much as 64 per cent $\left(\mathrm{II}_{300}\right.$, figs 4 and 6). Within the ara-C concentrations range $50-300 \mu \mathrm{g} / \mathrm{ml}$ the mean value of the index in the second wave of mitosis was proportional to the inhibitor concentration during incubation (Fig. 6). This relation was not found only in the case of the highest concentration applied $(500 \mu \mathrm{g} / \mathrm{ml})$. The mean value of the mitotic index (for the roots of both bulbs) after $12 \mathrm{~h}$ of postincubation was much lower than in those incubated in ara-C of 100 and $300 \mu \mathrm{g} / \mathrm{ml}$ concentrations, and it amounted to as little as 23.5 per cent (Figs 5 and 6). An exception here are also onion roots incubated in ara-C of $50 \mu \mathrm{g} / \mathrm{ml}$ concentration, among which a pronounced peak of mitoses appeared after $12 \mathrm{~h}$ of postincubation only in the roots of one bulb (Fig. 2).

\section{P L A T E I}

Mitotic activity in the apical meristem of onion roots incubated in ara-C

Photo 1. Mitoses in roots of control bulbs

Photo 2. Inhibition of mitotic activity, $300 \mu \mathrm{g} / \mathrm{ml}$ ara-C, $24+0$

Photo 3. Beginning of synchronized mitoses (prophase wave), $300 \mu \mathrm{g} / \mathrm{ml}$ ara-C, $24+10$

Photo 4. Wave of mitotic end phases, $300 \mu \mathrm{g} / \mathrm{ml}$ ara-C, $24+14$

$$
\text { PLATE II }
$$

Beginning of synchronic mitosis wave, $300 \mu \mathrm{g} / \mathrm{ml}$ ara-C, $24+12$

$$
\text { P L A T E III }
$$

Chromosome aberrations and micronuclei in apical meristem cells from onion roots incubated with ara $-\mathrm{C}$

Photos 1 -3. Chromosome aberrations in telophase, $300 \mu \mathrm{g} / \mathrm{ml}$ ara-C, $24+16$

Photos 4 and 5. Chromosome aberration in telophase $300 \mu \mathrm{g} / \mathrm{ml}$ ara-C, $24+10$ Photos 6 and 7. Cells with micronuclei, $500 \mu \mathrm{g} / \mathrm{ml}$ ara-C, $24+22$

Photo 8. Micronucleus in a cell, $100 \mu \mathrm{g} / \mathrm{ml}$ ara-C, $24+6$

Photo 9. Micronucleus in a cell, $300 \mu \mathrm{g} / \mathrm{ml}$ ara-C, $24+14$ 


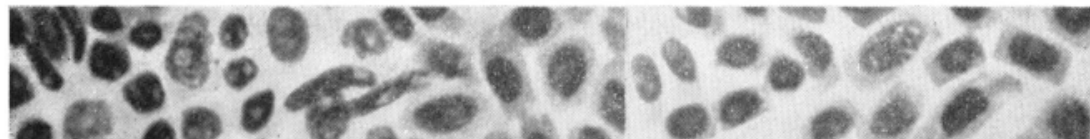

Pollo: *.6.

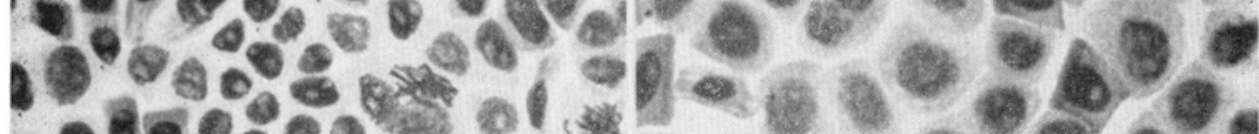
800.00 of

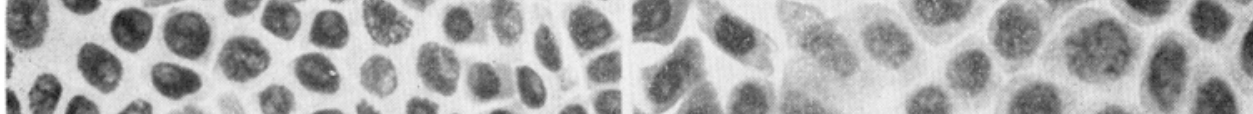

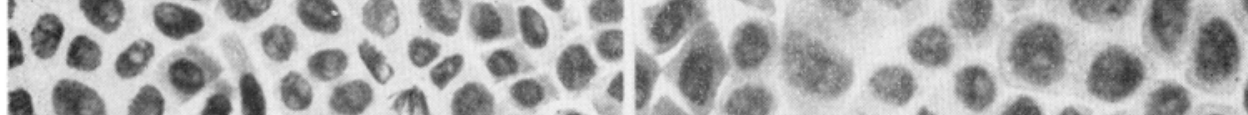

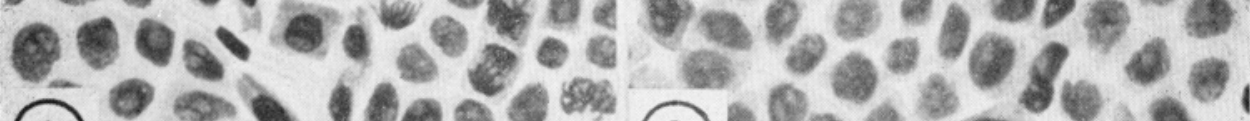

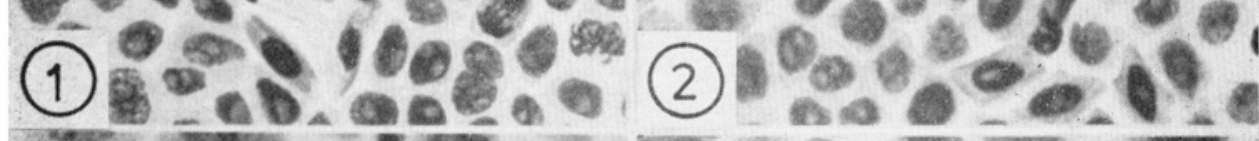
bes of

\section{8 \\ c \\ 19

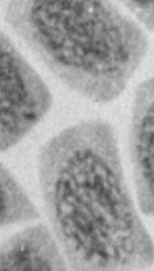

9

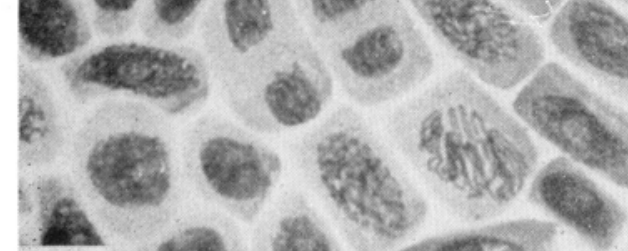

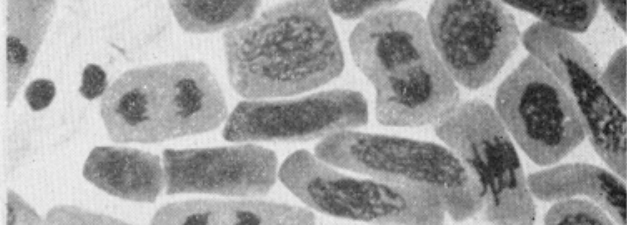

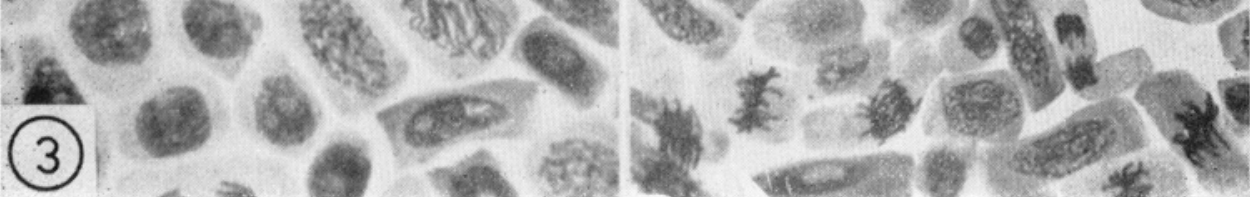




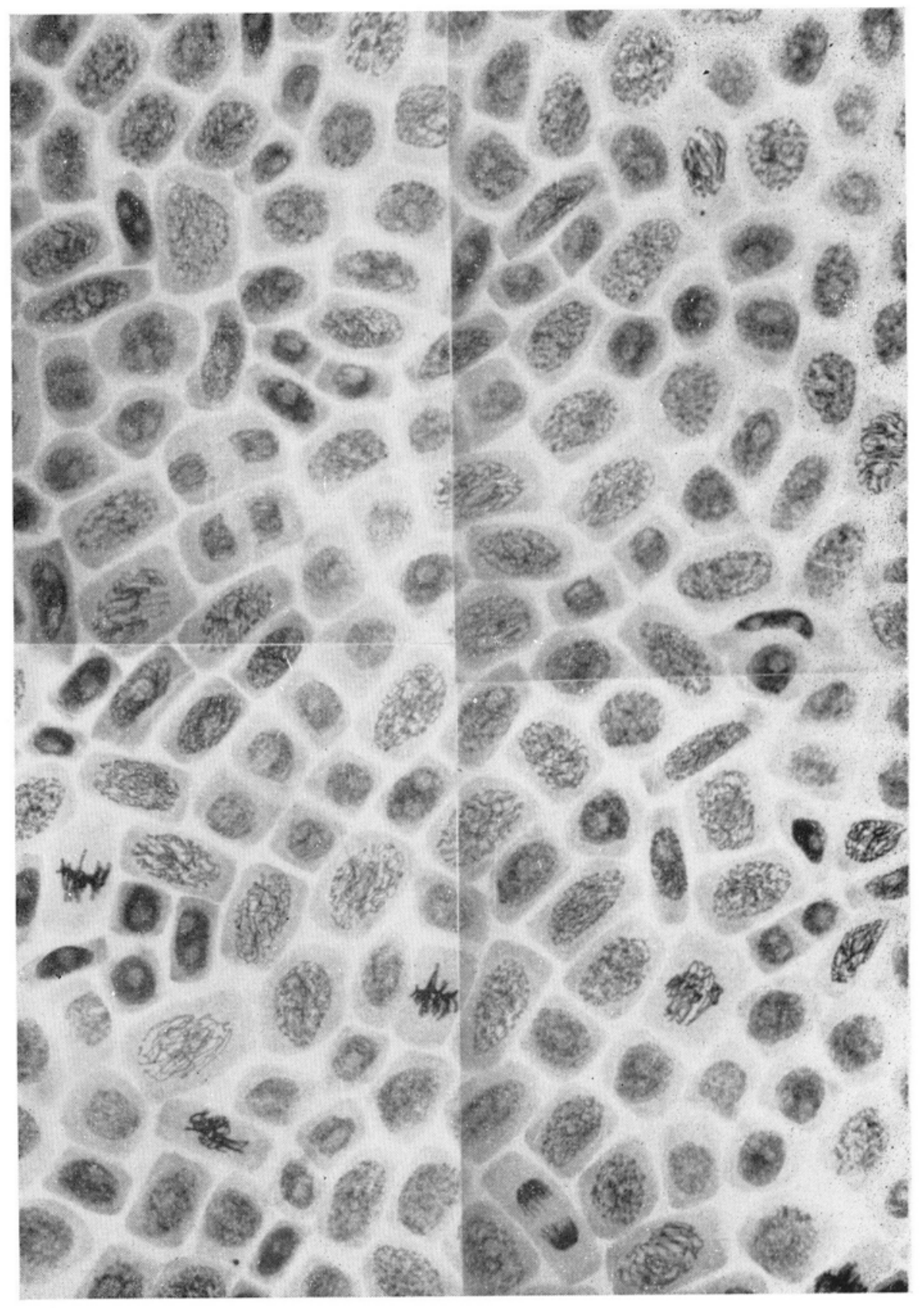




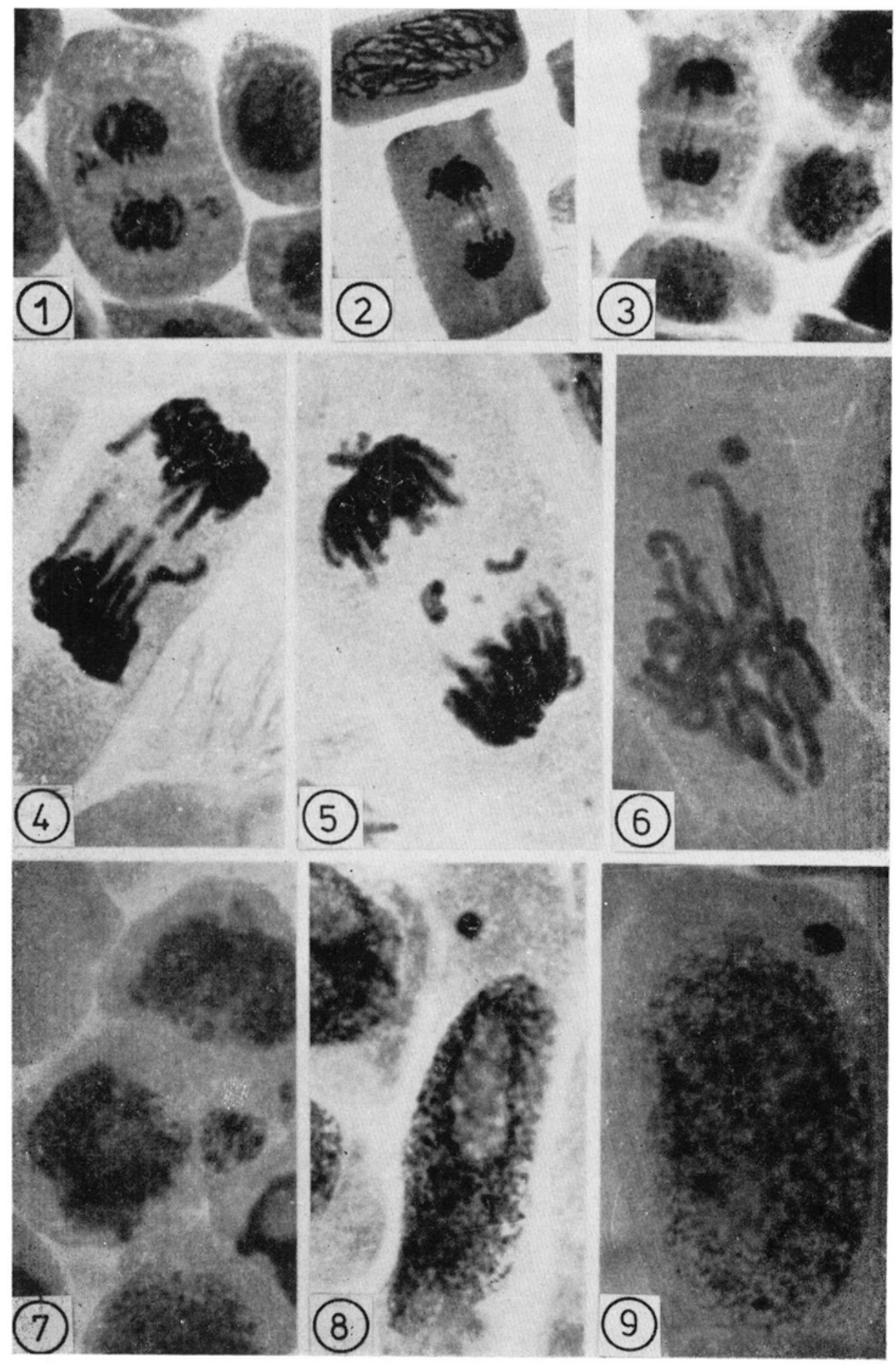


After the second peak of mitotic activity there occurred in all combinations a depression once more, and then in some roots a new increase in the frequency of mitoses up to a third successive peak of activity. Finally in the end of the postincubation period the mean mitotic index in all roots returned to the control level (Figs $1-6)$.

\section{Influence of ara-C on the phase indices}

There occurred during the whole experiment rather wide variations in the phase indices of individual roots of the same control bulb. The changes in the course of the mean curves plotted for the phase indices of roots of both bulbs were much less pronounced (Fig. 7). The mean data, therefore, are a more reliable point of reference for the changes of the indices occurring under the influence of ara-C.

The means for the control roots varied within the limits $37.3-59.0$ per cent for the prophase index, 11.5-19.1 per cent for the metaphase index, 7.1-14.1 per cent for the anaphase and 16.4-36.8 per cent for the telophase indices. The overall mean values of phase indices were in the control roots: for prophase 44.8 , for metaphase 14.8 , for anaphase 11.1 and for telophase 28.4 per cent.

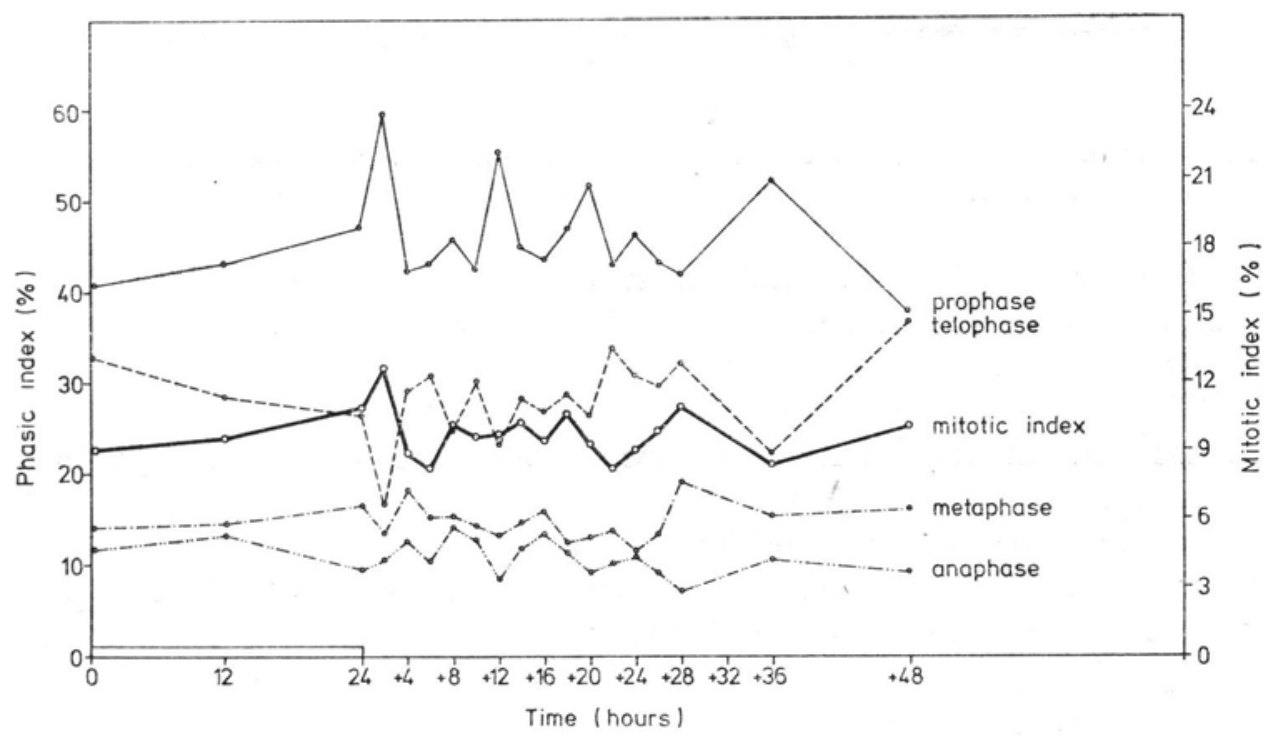

Fig. 7. Mitotic and phase indices in apical meristem of control onion roots

In the roots of the experimental bulbs considerable changes appeared in the proportions of the mitotic phases. During incubation an increase in the prophase index was noted at all ara-C concentrations 
(Figs $8-11$ ). With the rise of the prophase index there appeared changes in the indices of the remaining mitotic phases. The values of anaphase and telophase indices decreased in nearly all ara-C concentrations. The increase in the per cent of prophases concurrent with the decrease of the mitotic index indicates a protraction of prophase under the direct action of ara-C.

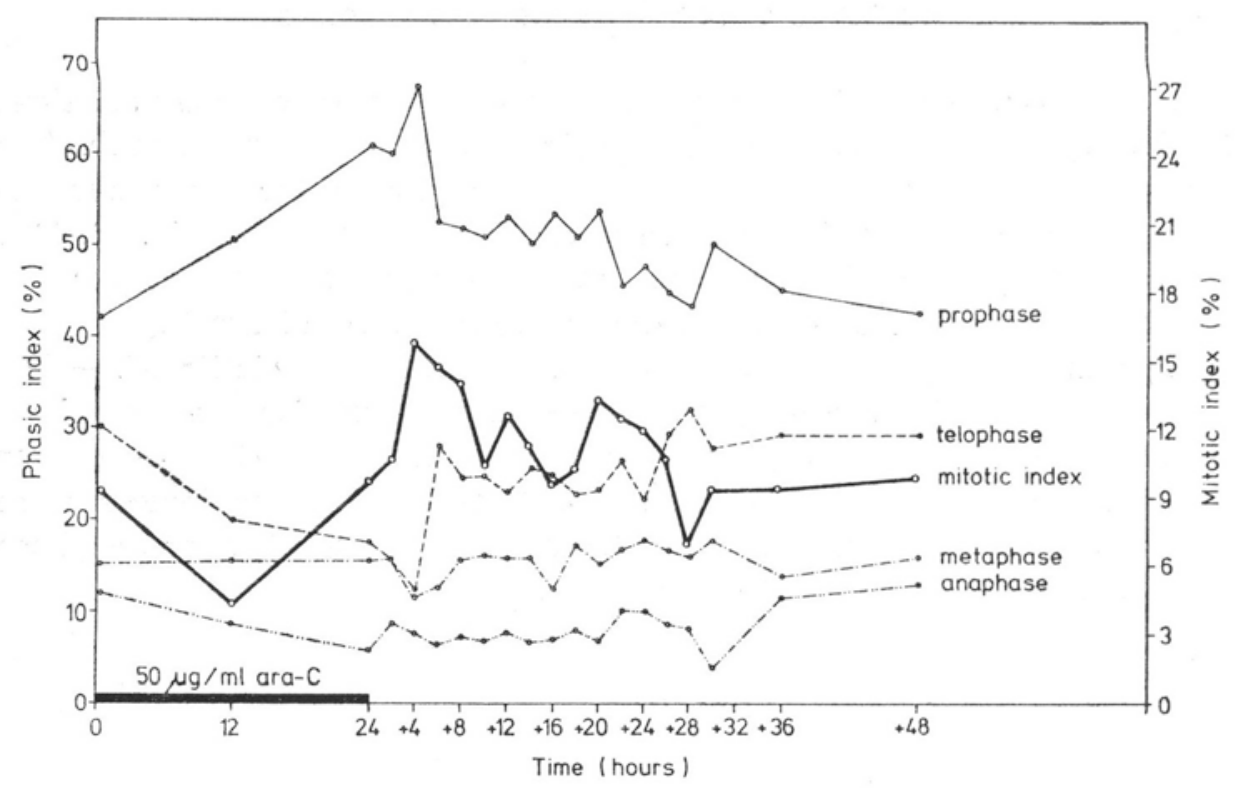

Fig. 8. Mitotic and phase indices in apical meristem of onion roots incubated for $24 \mathrm{~h}$ in $50 \mu \mathrm{g} / \mathrm{ml}$ ara-C and postincubated for $48 \mathrm{~h}$ in $\mathrm{H}_{2} \mathrm{O}$

The changes in phase indices in the period of postincubation are a consequence of resumption of mitotic activity and partial synchronization of mitoses.

The appearance after 2 or $4 \mathrm{~h}$ of postincubation of the first peak of mitoses is connected with the synchronous passing of the cells into prophase. The degree of synchronization in this period is proportional to the inhibitor concentration during incubation. Agreement in the time of appearance of the first peak of the mitotic index and that of the prophase index was observed in all ara-C concentrations from 50 to $300 \mu \mathrm{g} / \mathrm{ml}$ (Figs 8-10).

After the appearance of the first prophase peak, there occurred in the roots of most of the bulbs a decrease in the frequency of prophases and an increase in the percentage of metaphases, anaphases and telophases. Then a new wave of prophases (Plate I, fot 3 and Plate II) appeared constituting the beginning of the highest peak of mitosis occurring after $12 \mathrm{~h}$ of postincubation. 


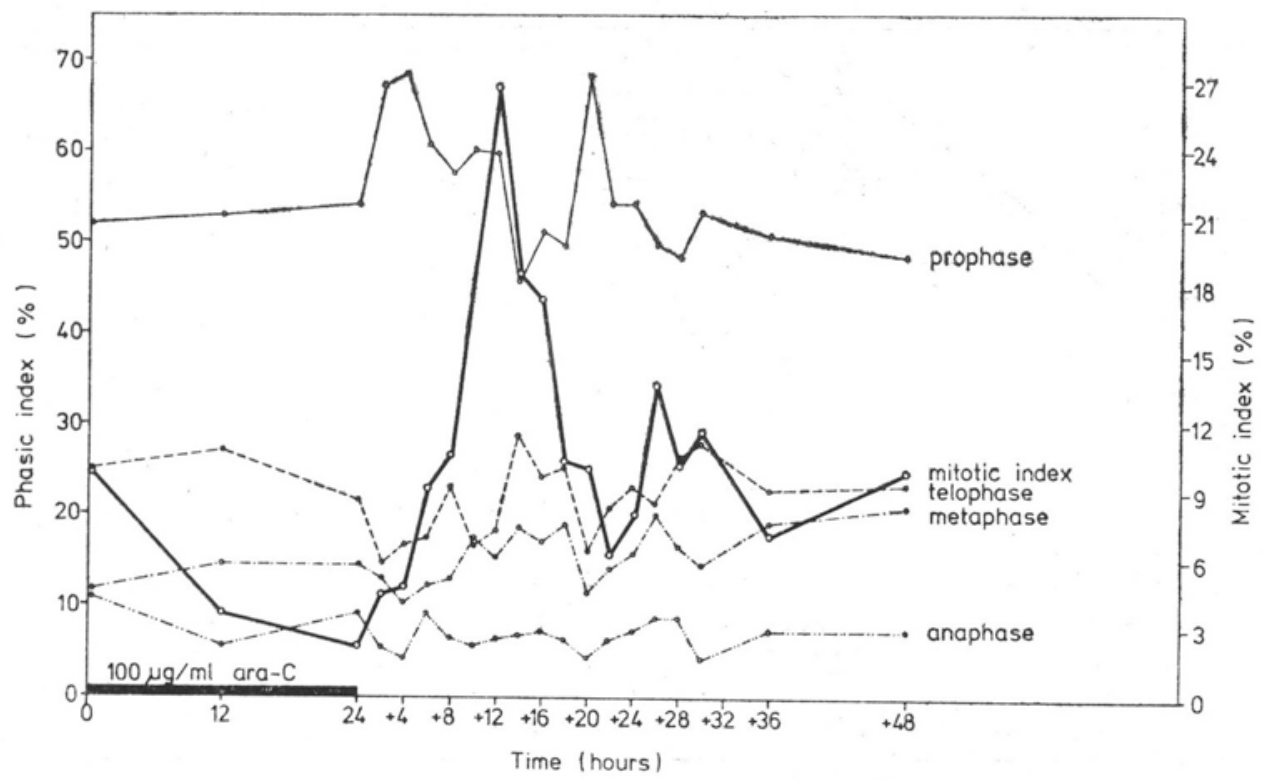

Fig. 9. Mitotic and phase indices in apical meristem of onion roots incubated for $24 \mathrm{~h}$ in $100 \mu \mathrm{g} / \mathrm{ml}$ ara-C and postincubated for $48 \mathrm{~h}$ in $\mathrm{H}_{2} \mathrm{O}$

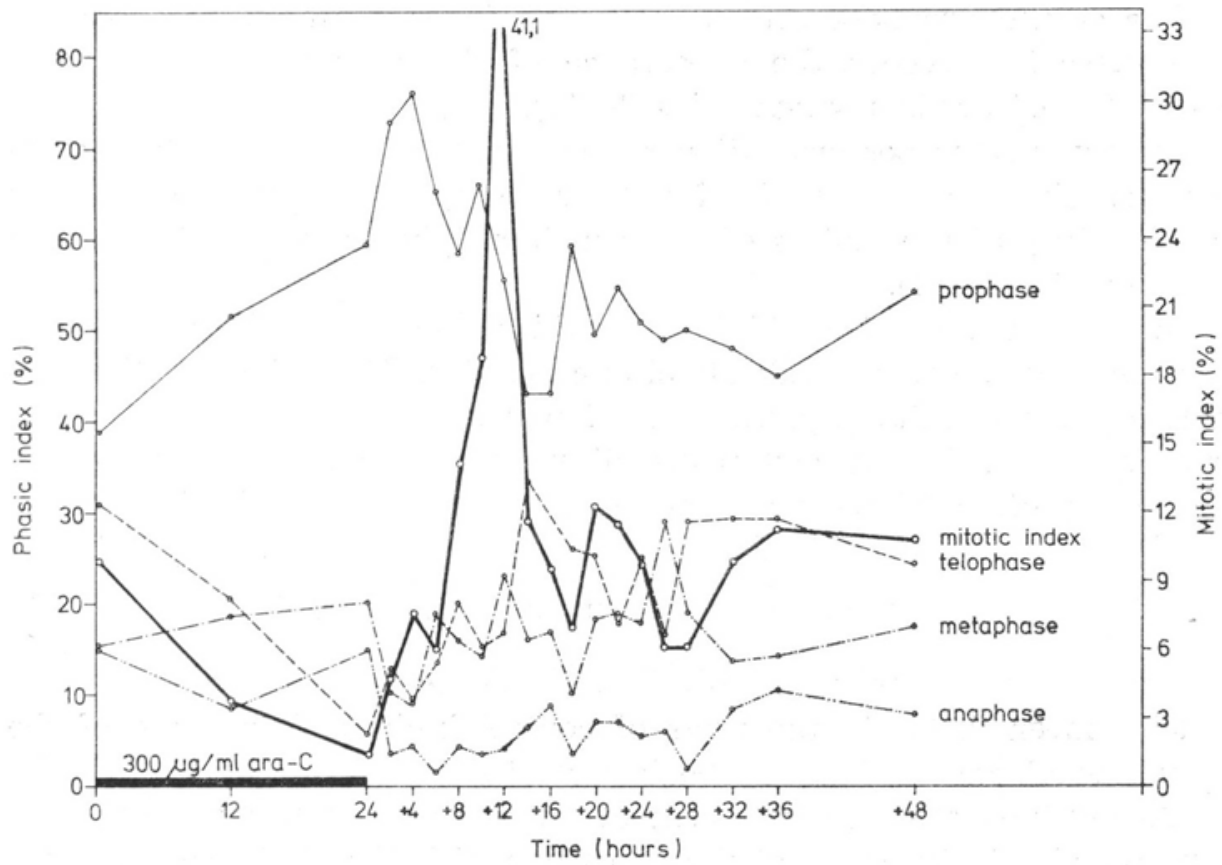

Fig. 10. Mitotic and phase indices in apical meristem of onion roots incubated for $24 \mathrm{~h}$ in $300 \mu \mathrm{g} / \mathrm{ml}$ ara-C and postincubated for $48 \mathrm{~h}$ in $\mathrm{H}_{2} \mathrm{O}$ 


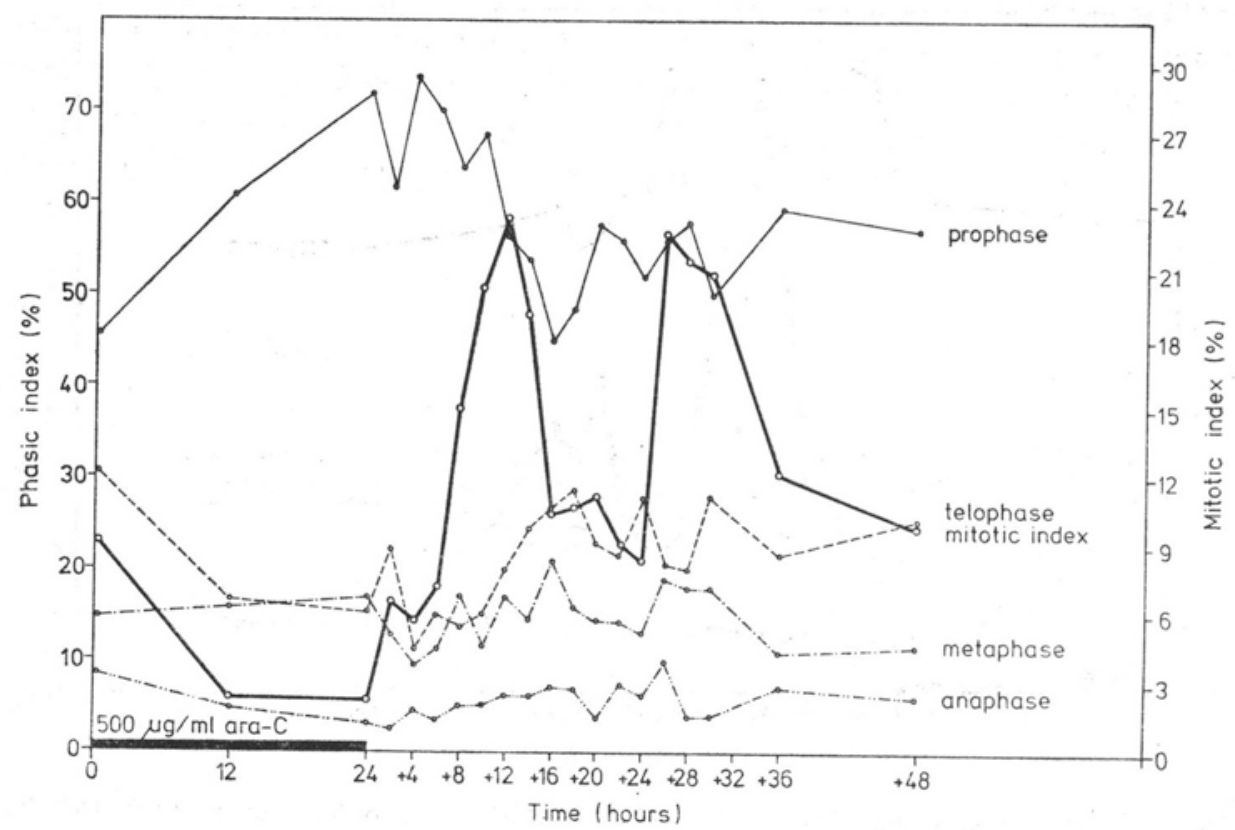

Fig. 11. Mitotic and phase indices in apical meristem of onion roots incubated for $24 \mathrm{~h}$ in $500 \mu \mathrm{g} / \mathrm{ml}$ ara-C and postincubated for $48 \mathrm{~h}$ in $\mathrm{H}_{2} \mathrm{O}$

The second prophase peak is as a rule lower than the first one. In most cases it precedes the appearance of the second peak of mitosis after $12 \mathrm{~h}$ of postincubation (Figs $9-11$ ).

During further postincubation a new depression of the prophase index was observed (12-18 h of postincubation) with simultaneous rise of the values of the indices of the remaining phases of mitosis (Plate I, photo 4; Figs 8-11).

In all experimental combinations a third wave of prophases was noted preceding the third peak of mitotic activity. The values of the successive peaks of mitotic phases were lower and lower as postincubation was prolonged. In the end phase of postincubation the index values for the experimental roots returned to the control level (Figs 7-11).

\section{Chromosome aberrations and micronuclei}

The per cent of mitoses with chromosome aberration was low $(0.0-$ $-1.5 \%$, mean $0.4 \%$ ) in the roots of control bulbs and in those of the experimental ones before the beginning of incubation.

During incubation the per cent of mitoses with chromosome aberrations remains in the roots of the experimental bulbs at the control level (not exceeding $0.5 \%$ ), and during postincubation it rises slightly reaching sporadically $1.5-2.0$ per cent. 
The control roots show very few cells with micronuclei $(0.0-0.4 \%)$. The number of cells with micronuclei does not increase in the experimental bulbs during incubation. In postincubation a gradual but slight increase of the per cent of cells containing micronuclei was observed. This increase was most pronounced after incubation in $500 \mu \mathrm{g} / \mathrm{ml}$ of ara-C (maximum $1.0 \%$ ).

\section{DISCUSSION}

Incubation of onions roots in ara-C solution of 100,300 and 500 $\mu \mathrm{g} / \mathrm{ml}$ concentration for $24 \mathrm{~h}$ produces $\mathrm{a} \pm 80$ per cent inhibition of mitotic activity. The mean mitotic index in all these combinations stabilizes at a 2 per cent level.

In the present study the mechanism of inhibition of mitotic activity was not investigated, it would seem, however, that it is the consequence of DNA synthesis inhibition. The inhibitory effect of ara-C on DNA synthesis in animal and human cells has been demonstrated among others by $\mathrm{Chu}$ and Fischer (1962), Cardeilhac and Cohen (1964) and Kimball and Wilson (1968).

The conclusion that the decreased frequency of mitoses is the consequence of the action of ara-C on phase $\mathrm{S}$ is supported indirectly by the results of the present study, particularly by the fact that the time required for full resumption of mitotic activity in the postincubation periods, manifested by a high mitotic wave is $12 \mathrm{~h}$ that is approximately as long as the transition in onion root meristem cells from the beginning of phase $\mathrm{S}$ to mitosis.

The incomplete inhibition of mitotic activity during incubation (even when concentrations toxic to the cells are used) may point to the occurrence at this time of DNA synthesis. This possibility is also indicated by the studies of Kimball and Wilson (1968) who affirm that $10^{-3} \mathrm{M}$ ara-C reduces in Ehrlich ascites cells thymidine incorporation into DNA by about 80 per cent.

It may be concluded from these data that DNA synthesis is greatly restricted and the phase S very prolonged, but not completely inhibited, in the presence of ara-C. On the other hand, the increase in the volume of nuclei during the incubation in ara-C reported by $\mathrm{Zimmerman}$ and $\mathrm{A} \mathrm{dh}$ a $\mathrm{m}$ i (1975), in a monolayer tissue culture from mouse embryo, and that observed by us in root apical meristem may be the effect of undisturbed RNA and non-histone protein synthesis, despite specific inhibition of DNA and histone synthesis. The occurrence of a manifold increase in the volume of nuclei without simultaneous DNA replication has been noted among others by Z obel (1975) in tannin cells of Sambucus. The inwestigations od Kimball and Wils on (1968) and Borun et al. (1967) demonstrated that ara-C shows no inhibitory in- 
fluence on RNA and non-histone protein synthesis. This is confirmed by the preliminary autoradiographic investigations of the present authors.

The results obtained in the present study also point to an inhibitory influence of ara-C on phase $G_{2}$, evidence of which is the increased per cent of mitoses as early as $2-4 \mathrm{~h}$ after abolition of the inhibitor action, and to the influence of ara-C on the course of mitosis, as indicated by the higher values of the prophase index during incubation. The influence on $\mathrm{G}_{2}$ and prophase may be the result of inhibition of histone protein synthesis (Bor un et al., 1967).

Significant for the mode of action of ara-C is the fact that the main peak of mitotic activity occurs after the same lapse of time $(12 \mathrm{~h}$ of postincubation) in the roots of all the experimental bulbs, notwithstanding the concentration applied during incubation. On the other hand, after other DNA synthesis inhibitors the delay in resumption of mitotic activity in the postincubation period increases as the concentration of the inhibitor (fluorodeoxyuridine, hydroxyurea and nalidixic acid) rises - unpublished data, studies, under the guidance of professor H. T e l e ż y ń s ki.

It is noteworthy that, in spite of application of high ara-C concentrations, its influence on the appearance of chromosome aberrations and micronuclei is slight.

The results of the present investigations suggest that cytosine arabinoside depresses DNA synthesis in the apical meristem of onion roots similarly as it does in animal and human cells. The negative result of Kihlman (1966) in experiments with Vicia faba roots seems to indicate that this species is resistant to the action of ara-C.

\section{Acknowledgment}

The authors are deeply indebted to professor H. Teleżyński for helpful discussions and valuable advice in the course of this work.

\section{REFERENCES}

Borun T. W., Scharff M. D., and Robbins E., 1967. Rapidly labeled, polirybosome associated RNA hawing the properties of hostone messenger. Proc. Nat. Acad. Sci. Wash. 58: $1977-1983$.

$\mathrm{Chu}$ M. Y. and G. A. Fis cher, 1962. A proposed mechanism of action of 1-B-D-arabinofuranosyl-cytosine as inhibitor of the growth of leukemic cells.

Bioch. Pharmac., 11: $422-430$.

Cardeilhac P. T., and Cohen S. S., 1964. Some metabolic properties of 1-B-D-arabinofuranosyl-cytosine. Cancer Res. 24: 1595 - 1603.

Evans I. S., and Mengel, G. D., 1964. The reversal of cytodine arabinoside activity in vivo by bleoxycytide. Biochem. Pharmacol. 13: $989-994$.

Kihlman B. A., Nichols W. W., and Levan A., 1963. The effect of deoxy- 
adenosine and cytosine arabinoside on the chromosomes of human leucocytes in vitro. Hereditas, 50: $139-143$.

Kihlman B. A., 1966. Actions of chemicals on dividing cells, Prentice - Hall Inc. Englewood Cliffs, New Jersey.

Kimball A. P. and Wils on M. J., 1968. Inhibition of polymerase DNA by 1-B-D-arabinosylcytosine and reversal of the inhibition by deoxytidino-5'triphosphate. Proc. Soc. exper. Biol. Medic. 127: 429-432.

Lopez-Saez J. P., Fernandez - Gomez E., 1965. Partial mitotic index and phase indices. Experientia, 21, $591-592$.

$\mathrm{Zimmermann} \mathrm{B.} \mathrm{and} \mathrm{H.} \mathrm{Aldhami,} \mathrm{1975.} \mathrm{Change} \mathrm{of} \mathrm{nuclear} \mathrm{size} \mathrm{in} \mathrm{mono-}$ layer cells from embryonic mouse brain under the influence of cytosine arabinoside. Z. mikrosk.-anat. Forsch., Leipzig, 89 (4): $632-639$.

Zobel A. M., 1975. Mixoploidy of tanin coenocytes in Sambucus racemosa L. Acta Soc. Bot. Pol., 44: $491-500$.

\section{Author's address}

Dr. Mieczysław Kuraś, Agnieszka Malinowska

Institute of Botany, Warsaw University;

Krakowskie Przedmieście 26/28; Warszawa; Poland

\section{Wpływ 1-ß-D-arabinofuranosylcytozyny na aktywność mitotyczna} merystemu wierzcholkowego korzeni przybyszowych cebuli jadalnej (Allium cepa L.)

Streszczenie

Zbadano wpływ rosnących stężeń $(50,100,300$ i $500 \mu \mathrm{g} / \mathrm{ml})$ cytozyny arabinozydu (ara-C) na aktywność mitotyczną komórek merystemu wierzchołkowego korzeni przybyszowych cebuli jadalnej (Allium cepa L.), w czasie 24 godz. inkubacji w ara-C i postinkubacji w wodzie.

Inkubacja w ara-C hamuje odwracalnie mitozy a stopień inhibicji aktywności mitotycznej zależny jest od stężenia ara-C: inkubacja korzeni w roztworze o stężeniu $50 \mu \mathrm{g} / \mathrm{ml}$ powoduje jedynie nieznaczne i przemijające obniżenie procentu mitoz, ara-C o stężeniu od 100 do $500 \mu \mathrm{g} / \mathrm{ml}$ obniża procent mitoz po 12 godz. inkubacji w różnym stopniu a po 24 godz. do jednakowego poziomu ca $2 \%$.

W okresie postinkubacji w wodzie występuje po stężeniu $100-500 \mu \mathrm{g} / \mathrm{ml}$ ara-C fala mitoz o wysokim stopniu synchronizacji. Największe $\left(60^{\circ} \%\right)$ nagromadzenie synchronicznych mitoz występowało po 12 godz. postinkubacji korzeni inkubowanych $\mathrm{w}$ ara-C o stężeniu $300 \mu \mathrm{g} / \mathrm{ml}$, co świadczy o zahamowaniu przez ara-C przemian interfazowych $\mathrm{w}$ fazie $\mathrm{S}$.

Stwierdzono, że pod wpływem ara-C tylko nieznacznie zwiększa się procent mitoz z aberracjami chromosomów i procent komórek z mikrojądrami. 